\title{
Spontaneous Expression of the c-sis Gene and Release of a Platelet-derived Growth Factorlike Molecule by Human Alveolar Macrophages
}

\author{
Jean-Francois Mornex, Yves Martinet, Kohei Yamauchi, Peter B. Bitterman, Gary R. Grotendorst, \\ Anna Chytil-Weir, George R. Martin, and Ronald G. Crystal \\ Pulmonary Branch, National Heart, Lung, and Blood Institute, and Laboratory of Developmental Biology and Anomalies, National \\ Institute of Dental Research, National Institutes of Health, Bethesda, Maryland 20892; and Division of Rheumatology \\ and Immunology, Department of Medicine, Medical University of South Carolina, Charleston, South Carolina 29425
}

\begin{abstract}
Alveolar macrophages from normal individuals and patients with interstitial lung diseases spontaneously expressed a 4.2-kilobase mRNA complementary to the c-sis gene, a proto-oncogene coding for one of the chains of platelet-derived growth factor (PDGF). Concomitantly, these cells released a mediator with the properties of PDGF, including: (a) chemotactic factor for smooth muscle cells whose activity was resistant to heat and acid, but sensitive to reduction; (b) mitogenic (competence) activity for fibroblasts; (c) ability to compete with PDGF for its receptor; and (d) precipitated by an anti-PDGF antibody. While blood monocytes did not contain c-sis mRNA transcripts, monocytes matured in vitro expressed c-sis, consistent with the concept that expression of c-sis occurs during the differentiation of monocytes into alveolar macrophages. Together with the known actions of PDGF, these observations suggest that the c-sis proto-oncogene and its PDGF product are part of the armamentarium available to the alveolar macrophages for normal lung defense and participation in lung inflammation.
\end{abstract}

\section{Introduction}

The alveolar macrophage is the pulmonary representative of the mononuclear phagocyte system, a group of cells that includes bone marrow precursors, blood monocytes, and tissue macrophages. Like tissue macrophages elsewhere, alveolar macrophages direct a variety of processes that form the front line defense against infectious agents, neoplastic cells, and xenobiotics (1). In addition, the alveolar macrophage plays a central role in the pathogenesis of acute and chronic inflammatory diseases of the lower respiratory tract by virtue of its ability to directly injure normal tissue components, recruit and activate other inflammatory cells, and direct the repair of injured tissues by recruiting mesenchymal cells and stimulating them to proliferate (2).

To a large extent, the alveolar macrophage is capable of these functions because it can release an armamentarium of mediators with diverse biologic functions (3). In this regard, it is the purpose of the present communication to demonstrate that included in this armamentarium is the expression of the c-sis gene, a proto-

Address reprint requests to Room 6D03, Building 10, National Institutes of Health, Bethesda, MD 20892. Dr. Mornex's present address is Hopital Louis Pradel, 69394 Cedex 3, Lyon, France, and Dr. Bitterman's present address is Pulmonary Division, University of Minnesota, Minneapolis, MN 55455.

Received for publication 21 November 1985.

The Journal of Clinical Investigation, Inc.

Volume 78, July 1986, 61-66 oncogene found on chromosome 22 that codes for one of the chains of platelet-derived growth factor (PDGF). ${ }^{1}$ Furthermore, alveolar macrophages spontaneously release a protein with the biochemical, antigenic, and functional characteristics of PDGF. In this context, since PDGF is capable of recruiting mesenchymal cells as well as inflammatory cells, and can stimulate mesenchymal cells to enter the early phase of the cell cycle (4-13), it is reasonable to conclude that expression of the c-sis proto-oncogene may play a central role in the normal processes of host defense and in the pathogenesis of nonmalignant inflammatory disorders.

\section{Methods}

Cell evaluation. Alveolar macrophages were obtained by bronchoalveolar lavage (14) from normal nonsmokers $(n=9)$, normal smokers with no evidence of lung disease $(n=5)$, and individuals with idiopathic pulmonary fibrosis (IPF; $n=14$ ), sarcoidosis $(n=6)$, and histiocytosis-X $(n=2)$. For extraction of RNA, alveolar macrophages were analyzed immediately. For evaluation of the spontaneous release of mediators, the alveolar macrophages were cultured $\left(24 \mathrm{~h}, 37^{\circ} \mathrm{C}, 4 \times 10^{6} \mathrm{cells} / \mathrm{ml}\right.$ in Dulbecco's modified Eagle's medium (DME) and $50 \mu \mathrm{g} / \mathrm{ml}$ gentamicin). Where indicated, cycloheximide $(10 \mu \mathrm{g} / \mathrm{ml})$ was added at the beginning of the culture.

For comparison to the alveolar macrophages, monocytes and in vitro matured macrophages were used as a source of RNA. Blood monocytes were prepared from leukopheresis of normal individuals (15); these cells were evaluated fresh or matured in vitro (16). As a control for c-sis expression, RNA was evaluated from T-24, a human bladder carcinoma cell line (ATCC HTB-4), and human placental RNA, sources known to contain c-sis messenger RNA (mRNA) transcripts $(17,18)$.

Purification of RNA and Northern analysis. Total cellular RNA was extracted with guanidine hydrochloride and purified by $\mathrm{CsCl}$ centrifugation (19). All samples had intact ribosomal RNA. Some samples, as indicated, were enriched in mRNA by single-step oligo dT cellulose chromatography (20). Total cellular RNA or poly(A) ${ }^{+}$-selected RNA was electrophoresed in denaturing conditions (21) followed by Northern analysis (22). Molecular weight standards included 18S and 28S RNA and ${ }^{32} \mathrm{P}$-labeled $\lambda$-DNA Hind III fragments. c-sis mRNA was detected using a c-sis human complementary DNA (cDNA) (plasmid pL-335, subclone of $\lambda$-L33, containing exons 6 and 7; provided by E. Gelmann, National Cancer Institute, Bethesda, MD) (7). As a control, actin mRNA was detected using a human fibroblast cytoplasmic $\gamma$-actin cDNA (plasmid pHF $\gamma$ A-1; provided by P. Gunning and L. Kedes, Stanford University, Stanford, CA) (23).

Characterization of the alveolar macrophage mediator. The spontaneous release of a PDGF-like mediator by alveolar macrophages was evaluated by testing macrophage supernatants for: $(a)$ chemotactic activity for smooth muscle cells (SMC); (b) stability to heat and acid, and sensitivity to reduction; (c) ability to provide competence activity for fibro-

1. Abbreviations used in this paper: DME, Dulbecco's modified Eagle's medium; IL-1, interleukin 1; IPF, idiopathic pulmonary fibrosis; PDGF, platelet-derived growth factor; SMC, smooth muscle cells. 
blast growth in a complementation test; $(d)$ competition with PDGF for its receptor on fibroblasts; and $(e)$ antigenic behavior in a radioimmunoassay with anti-PDGF antibody. PDGF was purified from platelets (purity was assessed by sodium dodecyl sulfate gel electrophoresis and amino acid composition to be $>99 \%$ ) and was used to prepare goat antiPDGF antiserum that specifically immunoprecipitated labeled PDGF as well as ${ }^{35} \mathrm{~S}-\mathrm{v}$-sis product.

Macrophage supernatants were tested for SMC chemotactic activity using bovine aorta SMC as targets (24). For each condition, the number of migrating cells was quantified as previously described (25). PDGF (5 $\mathrm{ng} / \mathrm{ml}$ ) and DME alone were used as controls. The biochemical properties of the SMC chemotactic activity in macrophage supernatants were evaluated as: (a) stability to trypsin $(100 \mu \mathrm{g} / \mathrm{ml}$, Worthington Diagnostic Systems, Inc., Freehold, NJ; $30 \mathrm{~min}, 37^{\circ} \mathrm{C}$, then inhibited by soybean trypsin inhibitor, $200 \mu \mathrm{g} / \mathrm{ml}$, Worthington Diagnostic Systems, Inc.); (b) stability to heat $\left(100^{\circ} \mathrm{C}, 10 \mathrm{~min}\right) ;(c)$ stability to acid (pH 2.5, $\left.30 \mathrm{~min}\right)$; and $(d)$ stability to reduction (2-mercaptoethanol, final concentration 2 $\left.\mathrm{mM}, 30 \mathrm{~min}, 22^{\circ} \mathrm{C}\right)$; and $(e)$ inhibition by anti-PDGF antibody $(30 \mathrm{~min}$, $22^{\circ} \mathrm{C}$ ). The ability of the alveolar macrophage mediator with SMC chemotactic activity to provide competence activity for fibroblast growth was demonstrated after partially purifying the mediator by carboxymethyl cellulose chromatography eluted with a linear $\mathrm{NaCl}$ gradient. This procedure insured that we were not evaluating fibronectin, a known alveolar macrophage-produced "competence" factor for fibroblast growth (26). The fractions $(0.30-0.35 \mathrm{M} \mathrm{NaCl})$ with SMC chemotactic activity were pooled and tested for growth activity for fibroblasts in a complementation test using diploid human lung fibroblasts (HFL-1; ATCC CCL 153) (27). The partially purified mediator was added $(94 \mu \mathrm{g} / \mathrm{ml})$ to noncycling fibroblasts with or without the progression factor insulin $(50 \mu \mathrm{g} / \mathrm{ml}$; Collaborative Research, Inc., Waltham, MA) or the competence factor PDGF $(25 \mathrm{ng} / \mathrm{ml})$; the cultures were maintained for $3 \mathrm{~d}$ and the cells counted.

PDGF receptor binding studies were performed as described by Heldin et al. (28). Pure ${ }^{125}$ I-PDGF ( $5 \mathrm{ng} ; 2 \times 10^{4} \mathrm{dpm} / \mathrm{ng}$ ) was added to growth density-arrested BALB/c-3T3 fibroblasts (ATCC CCL 163) together with dilutions of PDGF, fibroblast growth factor (Collaborative Research, Inc.), or concentrated macrophage supernatant (dialyzed against $1 \mathrm{M}$ acetic acid, lyophilized, and resuspended). The PDGF radioimmunoassay was performed using a goat antihuman PDGF IgG antibody. Dilutions of PDGF and of alveolar macrophage supernatants were added to antibody $\left(3 \mu \mathrm{g} / \mathrm{ml} ; 30 \mathrm{~min}, 22^{\circ} \mathrm{C}\right),{ }^{125} \mathrm{I}$-PDGF was added $\left(30 \mathrm{~min}, 22^{\circ} \mathrm{C}\right)$, and bound PDGF immunoprecipitated with $S$. aureus (CalbiochemBehring Corp., San Diego, CA).

Molecular sieve chromatography of the PDGF-like activity in the alveolar macrophage supernatants was carried out on Bio-Gel P-100 (Bio-Rad Laboratories, Richmond, CA) in $1 \mathrm{M}$ acetic acid after dialysis against $1 \mathrm{M}$ acetic acid, lyophilization, and reconstitution in $1 \mathrm{M}$ acetic acid. The chemotactic activity for SMC was tested for each fraction. Active fractions were subsequently tested for chemotactic and mitogenic activity with or without addition of anti-PDGF antibody.

All data are presented as the mean \pm standard error of the mean.

\section{Results}

Expression of the c-sis gene by alveolar macrophages. Evaluation of alveolar macrophages demonstrated that these cells spontaneously express the c-sis gene (Fig. 1). When total cellular RNA and/or poly $(\mathrm{A})^{+}$-selected RNA obtained from alveolar macrophages of normal nonsmokers, current cigarette smokers, and individuals with a variety of interstitial lung diseases was evaluated by Northern analysis using a labeled c-sis probe, a 4.2kilobase (kb) mRNA was detected. Although insufficient number of cells were available for analysis to quantify the amount of csis mRNA expressed per cell, it was clearly detected in all alveolar macrophage RNA samples evaluated. However, because of the limitation in the numbers of alveolar macrophages available, variable amounts of RNA were used for each lane and thus the

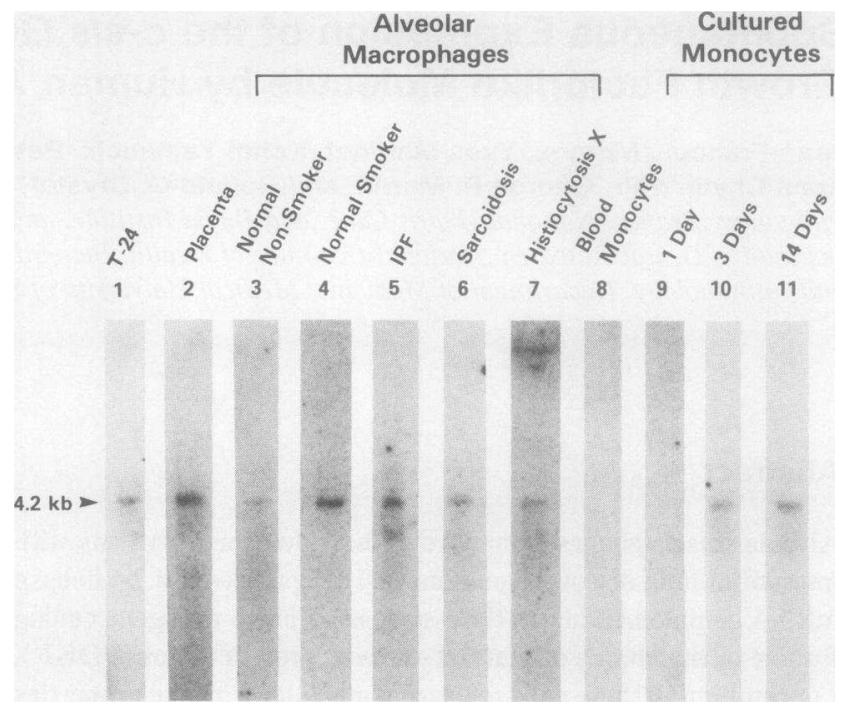

Figure 1. Expression of the c-sis gene by alveolar macrophages and blood monocytes. Shown are Northern blots of RNA hybridized to a ${ }^{32} \mathrm{P}$-labeled c-sis probe. The source of RNA in each lane is: (I) T-24 bladder carcinoma cells ( $20 \mu \mathrm{g}$ total RNA; $3 \times 10^{6}$ cells); (2) human placenta (30 $\mu \mathrm{g}$ total RNA; $4 \times 10^{6}$ cells); (3) alveolar macrophages of normal nonsmokers ( $4 \mu \mathrm{g}$ poly(A) ${ }^{+}$-enriched RNA; $10^{7}$ cells); (4) alveolar macrophages of normal smokers (20 $\mu \mathrm{g}$ total RNA; $7 \times 10^{6}$ cells); (5) alveolar macrophages of IPF ( $4 \mu \mathrm{g}$ poly(A) ${ }^{+}$-enriched RNA; $10^{7}$ cells); (6) alveolar macrophages of sarcoidosis (4 $\mu \mathrm{g}$ poly $(\mathrm{A})^{+}-$enriched RNA; $10^{7}$ cells); (7) alveolar macrophages of histiocytosis-X (6 $\mu \mathrm{g}$ poly $(\mathrm{A})^{+}$-enriched RNA; $10^{7}$ cells); ( 8$)$ fresh monocytes $(10 \mu \mathrm{g}$ total RNA; $8 \times 10^{6}$ cells); $(9)$ as lane 8 , cultured $1 \mathrm{~d}$; $(10)$ as lane 8 , cultured $3 \mathrm{~d}$; and $(11)$ as lane 8 , cultured $14 \mathrm{~d}$.

results are qualitative only. As a control, analysis of total cellular RNA obtained from tumor cell line T-24 and human placental RNA demonstrated a c-sis transcript of the same size. Occasionally, a fainter 2.6-kb band was also noted (for example, Fig. 1, lane 5). In contrast, no c-sis mRNA was detected in total RNA isolated from blood monocytes. However, when blood monocytes were cultured over a 14-d period, although not detectable after $1 \mathrm{~d}$, the c-sis transcript was present after 3 and 14 $\mathrm{d}$, which is consistent with the concept that c-sis expression is concomitant with the differentiation of monocytes into alveolar macrophages. In contrast to the studies with alveolar macrophages, these studies are quantitative (in a relative sense), since identical amounts of RNA were used for each lane. When the same RNA samples were analyzed with an $\gamma$-actin cDNA probe, a $2.0-\mathrm{kb}$ mRNA $\gamma$-actin was found in fresh blood monocytes as well as in in vitro matured monocytes and alveolar macrophages from all sources (not shown).

Spontaneous release of a PDGF-like mediator by alveolar macrophages. Supernatants of alveolar macrophages cultured for $24 \mathrm{~h}$ contained SMC chemotactic activity that was synthesized de novo and shared the physicochemical properties of PDGF (Fig. $2 A$ ). When supernatants of alveolar macrophages were placed in the lower chamber of a Boyden chamber, a chemotactic activity for SMC was observed. Checkerboard analysis demonstrated that the SMC chemotactic activity was truly chemotactic (not shown). The release of this activity was linked to de novo protein synthesis; $4.3 \pm 3.0 \%$ of the original activity was detected in parallel cultures incubated with cycloheximide. To put this chemotactic activity in context, PDGF $(5 \mathrm{ng} / \mathrm{ml})$ at- 

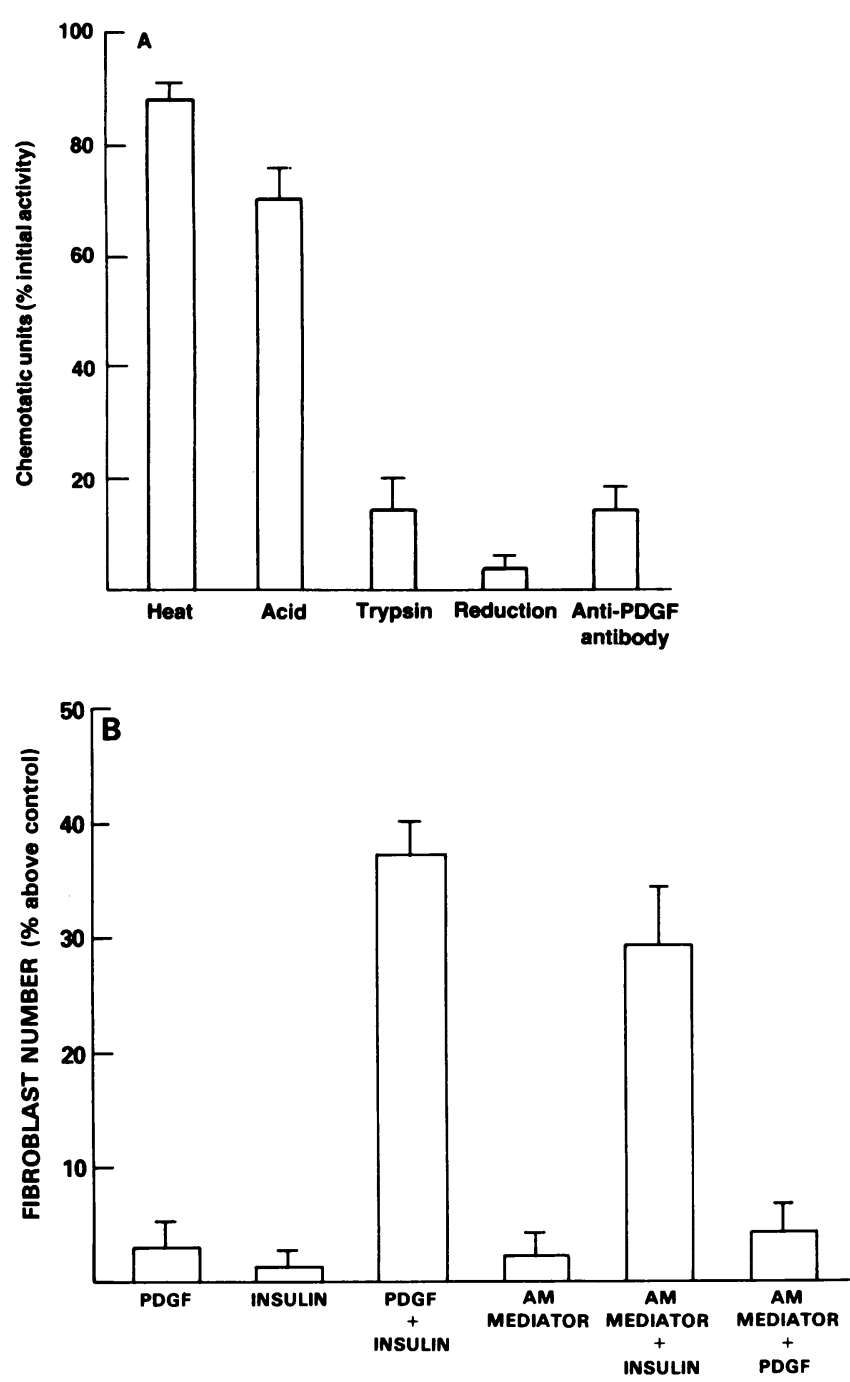

Figure 2. Spontaneous release by alveolar macrophages (AM) of a mediator with PDGF-like activity. $(A)$ Chemotactic activity for smooth muscle cells. Supernatants from normal AM were assayed for chemotactic activity alone and after heating, exposure to acid, trypsin, reduction, and anti-PDGF antibody. The results represent percent of initial chemotactic activity present after each treatment. The data represent the average for three samples for each condition. $(B)$ Competence growth promoting activity. The mediator responsible for the smooth muscle chemotactic activity in $A$ was partially purified (see text; referred to as "macrophage mediator" in the figure) and evaluated for fibroblast growth activity in a complementation test. Additions included: PDGF alone, insulin alone, PDGF + insulin, macrophage mediator alone, macrophage mediator + insulin, and macrophage mediator + PDGF. The increase in fibroblast number is expressed as the percent increase above control. Evaluation of the same fibroblasts with $\left[{ }^{3} \mathrm{H}\right]$ thymidine incorporation and autoradiography revealed: PDGF + insulin $34 \pm 3 \%$ labeled nuclei; partially purified AM mediator + insulin $26 \pm 3 \%$; all controls $<2 \pm 2 \%$ (AM mediator + insulin vs. controls $P<0.01$ ). The AM evaluated were from IPF patients; similar results were obtained with AM from other groups.

tracted the same number of SMC as the unfractionated supernatant. Evaluation of the SMC chemotactic activity in the macrophage supernatants demonstrated that (compared with native macrophage supernatant) it was sensitive to trypsin, mostly resistant to heat and acid, but was inactivated by reduction and by the addition of anti-PDGF antibody (Fig. $2 A$ ). Thus, the chemotactic activity observed was likely due to a PDGF-like molecule, although the small loss of activity with heat and acid is consistent with the possibility that a small proportion of the chemotactic activity is due to other mediators. Furthermore, like PDGF, the alveolar macrophage mediator with SMC chemotactic activity also demonstrated competence activity in a complementation assay for fibroblast growth (Fig. $2 \mathrm{~B}$ ). The partially purified mediator induced proliferation of growth-arrested fibroblasts in the presence of insulin, a progression factor. In contrast, by itself, or in the presence of PDGF, the macrophage mediator did not stimulate the growth of fibroblasts (alveolar macrophage mediator + insulin, $P<0.01$, compared with controls, a result similar to PDGF + insulin, $P>0.1$ ).

Consistent with the concept that alveolar macrophages produced a PDGF-like mediator, alveolar macrophage supernatant competed with ${ }^{125} \mathrm{I}$-PDGF for binding to the PDGF receptor on fibroblasts in a dose-dependent manner in a fashion similar to purified PDGF (Fig. $3 A$ ). Furthermore, a radioimmunoassay using anti-PDGF antibody demonstrated that the alveolar macrophage supernatants contained a molecule with antigenic properties remarkably similar to that of PDGF (Fig. $3 \mathrm{~B}$ ).

The similarity to PDGF was further confirmed by the coelution of the supernatant chemotactic activity and purified PDGF (Fig. 4). Furthermore, the fractions containing PDGF and alveolar macrophage supernatant chemotactic activity were suppressed by addition of anti-PDGF antibody. In a same manner the mitogenic activity present in fractions with chemotactic activity was inhibited by addition of anti-PDGF antibody (not shown).

\section{Discussion}

Alveolar macrophages express a 4.2-kb mRNA transcript of the c-sis gene and release a molecule with the biochemical, antigenic, and functional characteristics of PDGF, a mediator that can recruit and activate inflammatory cells, recruit mesenchymal cells, and stimulate mesenchymal cells to enter their cell cycle (4-6). This is true for normal alveolar macrophages as well as for alveolar macrophages participating in the chronic inflammation of a variety of human disorders. Since the c-sis gene codes for the B-chain (PDGF-2, peptide I) of PDGF $(12,13)$, these observations suggest that the c-sis gene, a segment of DNA on chromosome 22 that is homologous to the v-sis oncogene (7), likely contributes to the armamentarium used by the alveolar macrophage in normal host defense as well as in its role in the pathogenesis of inflammatory disorders of the lung.

PDGF, c-sis, and v-sis. PDGF is a 29,000-33,000-mol-wt glycoprotein composed of two chains linked by disulfide bridges (4-6). The complete structure of PDGF is not known, but the sequence of the B-chain has been identified $(8,12,13,29)$. The molecule exerts its function by binding to its target cells through a cell receptor thought to be a tyrosine kinase $(30,31)$. The major source of PDGF is the $\alpha$-granules of platelets; when platelets are activated, PDGF is released and thus PDGF is easily detected in serum (4-6). Other normal cells known to release PDGF include human endothelial cells (32), rat arterial SMC (33), human cytotrophoblast (18), and activated blood monocytes (34).

PDGF has the ability to attract and activate its target cells. It is a chemoattractant for SMC, fibroblasts, neutrophils, and monocytes, and provides a growth-promoting activity to fibroblasts, SMC, and glial cells (4-6). This mitogenic activity serves 

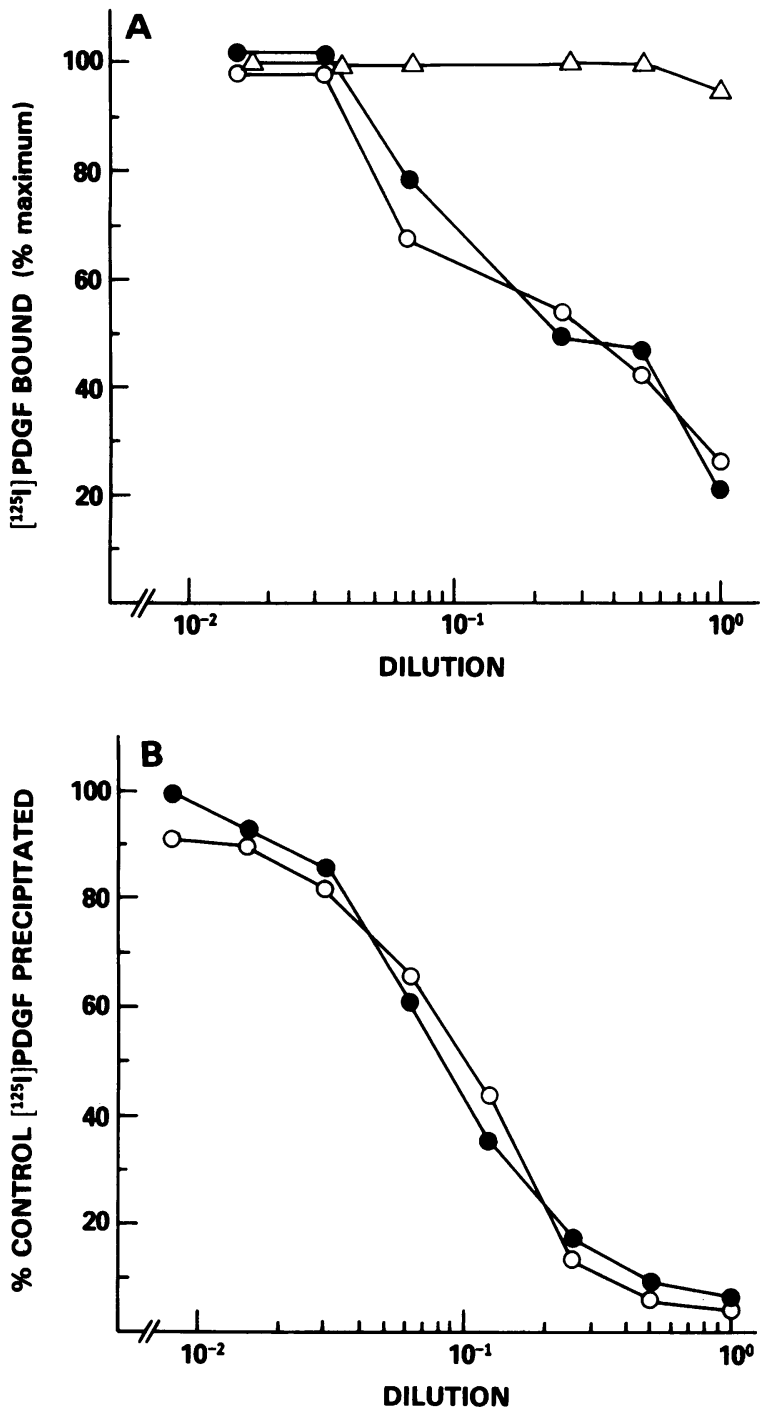

Figure 3. Characterization of the PDGF-like molecule spontaneously released by the alveolar macrophages using receptor binding competition and radioimmunoassay. $(A)$ Competition of the PDGF-like mediator in the alveolar macrophage supernatants with ${ }^{125}$ I-PDGF for binding to fibroblasts. $\circ$, Nonlabeled PDGF $(0$ dilution $=500 \mathrm{ng} / \mathrm{ml})$; -, alveolar macrophage supernatants ( 0 dilution $=10 \mathrm{mg}$ protein $/ \mathrm{ml})$; and $\Delta$, fibroblast growth factor ( 0 dilution $=1 \mu \mathrm{g} / \mathrm{ml})$ as a control. All assays were done in duplicate; the data represent the means for two experiments. (B) Radioimmunoassay. Dilutions of nonlabeled PDGF (O, starting concentration $10 \mathrm{ng} / \mathrm{ml}$ ) or alveolar macrophage supernatant $(\bullet)$ were added to anti-PDGF antibody in presence of ${ }^{125}$ I-PDGF and bound PDGF was immunoprecipitated. The data represent the means for two experiments. The alveolar macrophages evaluated in $A$ and $B$ were from IPF patients; similar results were obtained with alveolar macrophages from other groups.

as a "competence" signal that stimulates resting cells to enter the cell cycle and confers to cells the ability to respond to a "progression" signal, a second signal that is sufficient to cause the cells to proceed through the cell cycle and proliferate (35). PDGF also causes neutrophils to release oxidants and proteases and stimulates fibroblasts to release collagenase $(4-6,36)$.

A great deal of attention has been focused on PDGF because one of its component chains is coded for by the c-sis gene, a DNA sequence $30 \mathrm{~kb}$ long with $1.2-1.3 \mathrm{~kb}$ of $\mathrm{v}$-sis homologous

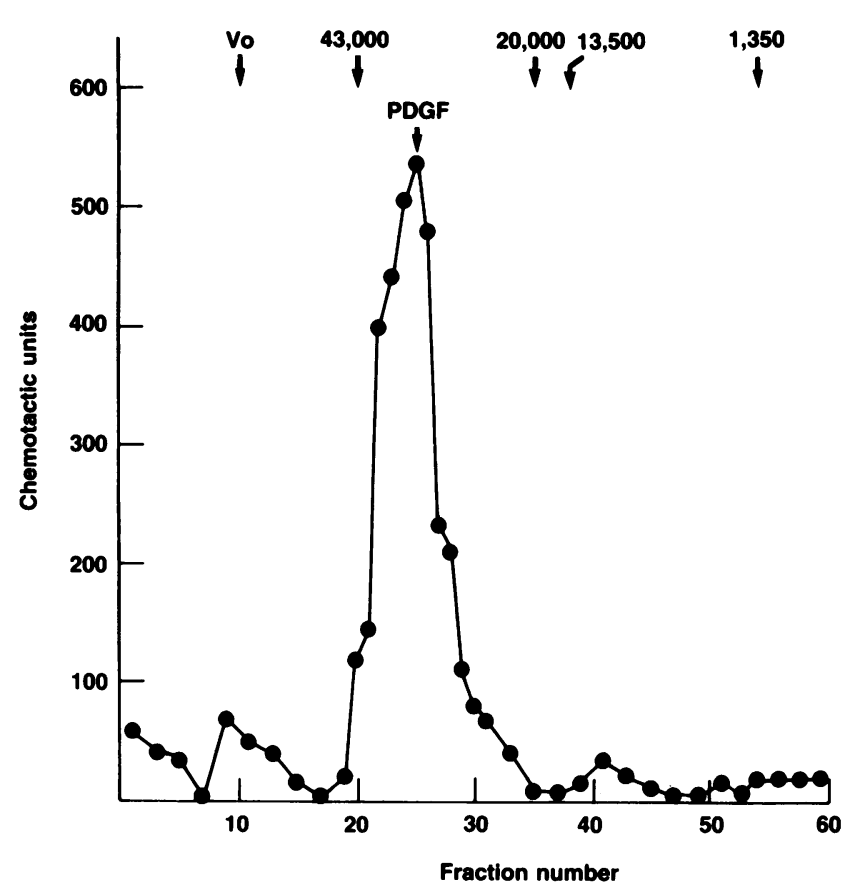

Figure 4. Molecular sieve analysis of the PDGF-like molecule spontaneously released by alveolar macrophages. Alveolar macrophage supernatant (500 ml, IPF patients) was dialyzed against $1 \mathrm{M}$ acetic acid, lyophilized, and chromatographed on Bio-Gel P-100. Each fraction was tested for chemotactic activity for SMC. Chromatography of pure PDGF on the same column is indicated as a molecular weight standard.

sequences, and at least seven exons (7-13). When $3 T 3$ fibroblasts are infected with $\mathrm{v}$-sis, they dedifferentiate and exhibit the features of uncontrolled proliferation characteristic of neoplastic cells (11). In the context of the mitogenic activities of PDGF for mesenchymal cells, the concept has developed that expression of v-sis and production of the v-sis product contributes to the process of transformation and uncontrolled proliferation of $\mathrm{v}$ sis-infected cells. Consistent with this, 3T3 cells transformed with v-sis exhibit the $\mathrm{p} 28^{\mathrm{v}-\mathrm{sis}}$ protein product, a protein analogous to the PDGF B-chain (9-13). Furthermore, a variety of cell lines derived from neoplastic tissues exhibit c-sis and/or a PDGFlike molecule, including human sarcoma (37) and glioma (38). In addition to a putative role for c-sis and PDGF in malignancy, there is increasing evidence that the c-sis gene and its product may contribute to processes of normal proliferation and differentiation. In this regard, mRNA transcripts of c-sis are found in placental trophoblasts (18), as well as in normal cultured human endothelial cells $(29,39)$. Although the contribution of PDGF to growth regulation of these malignant and normal cells is not fully understood, it is thought to be in the context of an autocrine growth factor, either associated with the cell membrane and/or secreted and subsequently acting through a specific cell surface receptor, that contributes to the network of signals modulating cell proliferation.

$P D G F, c$-sis, and alveolar macrophages. In contrast to the autocrine concepts that have evolved through the observations of c-sis expression in malignant and normal cells, the present study, as well as the recent report by Shimokado et al. (40), suggest that the c-sis PDGF-like product may also play a role in the arsenal of mediators that tissue macrophages use as effector molecules targeted to other cell types during normal host defense 
and in inflammatory disorders. Interestingly, while resting blood monocytes do not express c-sis, monocytes matured in vitro express c-sis, as do alveolar macrophages, a tissue macrophage that is derived from the blood monocyte. Consistent with the expression of c-sis, alveolar macrophages spontaneously release a molecule that has properties identical to PDGF. This observation is consistent with prior reports of molecules other than fibronectin (26) with competence-like growth activity released by macrophages $(40,41)$.

The observation that activated blood monocytes (34), monocytes matured in vitro, and unstimulated alveolar macrophages express c-sis and release the PDGF-like product is of interest when compared with the release by mononuclear phagocytes of other growth factors such as interleukin 1 (IL-1) and fibronectin. Like PDGF, blood monocytes do not spontaneously release IL-1, but do so when activated (42). However, in contrast to PDGF, monocytes matured in vitro and unstimulated alveolar macrophages do not spontaneously release IL1. Furthermore, unlike PDGF, stimulated monocytes do not release fibronectin, but like PDGF, in vitro matured monocytes and unstimulated alveolar macrophages constitutively release fibronectin $(42,43)$. Together, these observations suggest mononuclear phagocytes regulate the expression of the different genes coding for growth factors in different ways and that the expression of these genes by alveolar macrophages is not always similar to the manner in which they are expressed by blood monocytes.

The observation that alveolar macrophages constitutively release PDGF is of interest in the context that our previous evaluation of alveolar macrophage supernatants for this mediator failed to detect it (27). However, even though requiring a sensitive assay to detect it, PDGF is such a potent mediator (4-6) that it may turn out to be the dominant "competence" growth factor released by mononuclear phagocytes.

That human alveolar macrophages spontaneously express c-sis and release a PDGF-like molecule, together with the multipotential role of PDGF in recruiting and activating mesenchymal and inflammatory cells, is of particular interest in the chronic inflammatory disorders of the lower respiratory tract. These disorders are universally characterized by an accumulation of alveolar macrophages in the lung parenchyma (2). Although we have not been able to obtain sufficient numbers of those cells to accurately quantify the amount of c-sis mRNA transcripts they express compared with alveolar macrophages of normal individuals, and thus do not know whether the alveolar macrophages of individuals with inflammatory disease express similar or dissimilar amounts of c-sis mRNA transcripts, the knowledge that there are manyfold greater numbers of these cells in the lower respiratory tract in these disorders leads to the reasonable conclusion that the lungs of these individuals must contend with an increased burden of a PDGF-like molecule. In this context, it is likely that expression of c-sis and its product is part of the armamentarium of the alveolar macrophages that contributes, along with molecules such as fibronectin, alveolar macrophagederived growth factor, interleukin-1, fibroblast growth factor, and arachidonic acid metabolites, to the processes of inflammation and repair in these disorders $(2,3)$.

\section{References}

1. Mononuclear Phagocytes: Functional Aspects of Mononuclear Phagocytes. 1980. R. Van Furth, editor. K. Nijhoff, Boston.

2. Crystal, R. G., P. B. Bitterman, S. I. Rennard, A. J. Hance, and
B. A. Keogh. 1984. Interstitial lung diseases of unknown cause. Disorders characterized by chronic inflammation of the lower respiratory tract. $N$. Engl. J. Med. 310:154-166, 235-244.

3. Nathan, C. F., H. W. Murray, and Z. A. Cohn. 1980. The macrophage as an effector cell. N. Engl. J. Med. 303:622-626.

4. Deuel, T. F., and J. S. Huang. 1984. Platelet-derived growth factor. Structure, function, and roles in normal and transformed cells. J. Clin. Invest. 74:669-676.

5. Ross, R. 1981. The platelet-derived growth factor. In Handbook of Experimental Pharmacology, Vol. 57. R. Baserga, editor. SpringerVerlag, Berlin. 133-159.

6. Westermark, B., C.-H. Heldin, B. Ek, A. Johnsson, K. Mellström, M. Nistér, and Å. Wasteson. 1983. Biochemistry and biology of plateletderived growth factor. In Growth and Maturation Factors, Vol. 1. G. Guroff, editor. John Wiley \& Sons Inc., New York. 73-115.

7. Dalla Favera, R., E. P. Gelmann, R. C. Gallo, and F. Wong-Staal. 1981. A human onc gene homologous to the transforming gene ( $v$-sis) of simian sarcoma virus. Nature (Lond.). 292:31-35.

8. Waterfield, M. D., G. T. Scrace, N. Whittle, P. Stroobant, A. Johnsson, A. Wasteson, B. Westermark, C.-H. Heldin, J. S. Huang, and T. F. Deuel. 1983. Platelet-derived growth factor is structurally related to the putative transforming protein $\mathrm{p} 28^{\mathrm{sis}}$ of simian sarcoma virus. Nature (Lond.). 304:35-39.

9. Devare, S. G., E. P. Reddy, J. D. Law, K. C. Robbins, and S. A. Aaronson. 1983. Nucleotide sequence of the simian sarcoma virus genome: demonstration that its acquired cellular sequences encode the transforming gene product p28 sis. Proc. Natl. Acad. Sci. USA. 80:731735.

10. Doolittle, R. F., M. W. Hunkapiller, L. E. Hood, S. G. Devare, K. C. Robbins, S. A. Aaronson, and H. N. Antoniades. 1983. Simian sarcoma virus onc gene, v-sis, is derived from the gene (or genes) encoding a platelet-derived growth factor. Science (Wash. DC). 221:275-277.

11. Robbins, K. C., H. N. Antoniades, S. G. Devare, M. W. Hunkapiller, and S. A. Aaronson. 1983. Structural and immunological similarities between simian sarcoma virus gene product(s) and human platelet-derived growth factor. Nature (Lond.). 305:605-608.

12. Johnsson, A., C.-H. Heldin, Å. Wasteson, B. Westermark, T. F. Deuel, J. S. Huang, P. H. Seeburg, A. Gray, A. Ullrich, G. Scrace, P. Stroobant, and M. D. Waterfield. 1984. The c-sis gene encodes a precursor of the B chain of platelet-derived growth factor. EMBO (Eur. Mol. Biol. Organ.) J. 3:921-928.

13. Chiu, I.-M., E. P. Reddy, D. Givol, K. C. Robbins, S. R. Tronick, and S. A. Aaronson. 1984. Nucleotide sequence analysis identifies the human c-sis proto-oncogene as a structural gene for platelet-derived growth factor. Cell. 37:123-129.

14. Hunninghake, G. W., J. E. Gadek, O. Kawanami, V. J. Ferrans, and R. G. Crystal. 1979. Inflammatory and immune processes in the human lung in health and disease: evaluation by bronchoalveolar lavage. Am. J. Pathol. 97:149-206.

15. Bøyum, A. 1976. Isolation of lymphocytes, granulocytes, and macrophages. Scand. J. Immunol. 5(Suppl. 5):9-15.

16. Nakagawara, A., C. F. Nathan, and Z. A. Cohn. 1981. Hydrogen peroxide metabolism in human monocytes during differentiation in vitro. J. Clin. Invest. 68:1243-1252.

17. Bowen-Pope, D. F., A. Vogel, and R. Ross. 1984. Production of platelet-derived growth factor-like molecules and reduced expression of platelet-derived growth factor receptors accompany transformation by a wide spectrum of agents. Proc. Natl. Acad. Sci. USA. 81:2396-2400.

18. Goustin, A. S., C. Betsholtz, S. Pfeifer-Ohlsson, H. Persson, J. Rydnert, M. Bywater, G. Holmgren, C.-H. Heldin, B. Westermark, and R. Ohlsson. 1985. Coexpression of the sis and myc proto-oncogenes in developing human placenta suggests autocrine control of trophoblast growth. Cell. 41:301-312.

19. Glisin, V., R. Crkvenjakov, and C. Byus. 1974. Ribonucleic acid isolated by cesium chloride centrifugation. Biochemistry. 13:2633-2637.

20. Aviv, H., and P. Leder. 1972. Purification of biologically active globin messenger RNA by chromatography on oligothymidylic acid-cellulose. Proc. Natl. Acad. Sci. USA. 69:1408-1412. 
21. Lehrach, H., D. Diamond, J. M. Wozney, and H. Boedtker. 1977. RNA molecular weight determinations by gel electrophoresis under denaturing conditions, a critical reexamination. Biochemistry. 16:47434751 .

22. Thomas, P. S. 1980. Hybridization of denatured RNA and small DNA fragments transferred to nitrocellulose. Proc. Natl. Acad. Sci. USA. 77:5201-5205.

23. Gunning, P., P. Ponte, H. Okayama, J. Engel, H. Blau, and L. Kedes. 1983. Isolation and characterization of full-length cDNA clones for human $\alpha$-, $\beta$-, and $\gamma$-actin mRNAs: skeletal but not cytoplasmic actins have an amino-terminal cysteine that is subsequently removed. Mol. Cell. Biol. 3:787-795.

24. Grotendorst, G. R., H. E. J. Seppä, H. K. Kleinman, and G. R. Martin. 1981. Attachment of smooth muscle cells to collagen and their migration toward platelet-derived growth factor. Proc. Natl. Acad. Sci. USA. 78:3669-3672.

25. Bleiberg, I., A. K. Harvey, G. Smale, and G. R. Grotendorst. 1985. Identification of a PDGF-like mitoattractant produced by NIH/ 3T3 cells after transformation with SV40. J. Cell. Physiol. 123:161-166.

26. Bitterman, P. B., S. I. Rennard, S. Adelberg, and R. G. Crystal. 1983. Role of fibronectin as a growth factor for fibroblasts. J. Cell Biol. 97:1925-1932.

27. Bitterman, P. B., S. I. Rennard, G. W. Hunninghake, and R. G. Crystal. 1982. Human alveolar macrophage growth factor for fibroblasts: regulation and partial characterization. J. Clin. Invest. 70:806-822.

28. Heldin, C.-H., B. Westermark, and Å. Wasteson. 1981. Specific receptors for platelet-derived growth factor on cells derived from connective tissue and glia. Proc. Natl. Acad. Sci. USA. 78:3664-3668.

29. Collins, T., D. Ginsburg, J. M. Boss, S. H. Orkin, and J. S. Pober. 1985. Cultured human endothelial cells express platelet-derived growth factor B chain: cDNA cloning and structural analysis. Nature (Lond.). 316:748-750.

30. Ek, B., B. Westermark, A. Wasteson, and C.-H. Heldin. 1982. Stimulation of tyrosine-specific phosphorylation by platelet-derived growth factor. Nature (Lond.). 295:419-420.

31. Huang, S. S., J. S. Huang, and T. F. Deuel. 1984. The plateletderived growth factor receptor protein is a tyrosine-specific protein kinase. In Cold Spring Harbor Conference Cell Proliferation and Cancer: The Cancer Cell, Vol. 1. Cold Spring Harbor Laboratory, New York. 43-49.

32. DiCorleto, P. E., and D. F. Bowen-Pope. 1983. Cultured endothelial cells produce a platelet-derived growth factor-like protein. Proc. Natl. Acad. Sci. USA. 80:1919-1923.
33. Nilsson, J., M. Sjölund, L. Palmberg, J. Thyberg, and C.-H. Heldin. 1985. Arterial smooth muscle cells in primary culture produce a platelet-derived growth factor-like protein. Proc. Natl. Acad. Sci. USA. 82:4418-4422.

34. Martinet, Y., P. B. Bitterman, J.-F. Mornex, G. R. Grotendorst, G. R. Martin, and R. G. Crystal. 1986. Activated human monocytes express the c-sis proto-oncogene and release a mediator showing PDGFlike activity. Nature (Lond.). 319:158-160.

35. Pledger, W. J., C. D. Stiles, H. N. Antoniades, and C. D. Sher. 1977. Induction of DNA synthesis in BALB/c 3T3 cells by serum components: reevaluation of the commitment process. Proc. Natl. Acad. Sci. USA. 74:4481-4485.

36. Bauer, E. A., T. W. Cooper, J. S. Huang, J. Altman, and T. F. Deuel. 1985. Stimulation of in vitro human skin collagenase expression by platelet-derived growth factor. Proc. Natl. Acad. Sci. USA. 82:41324136.

37. Graves, D. T., A. J. Owen, R. K. Barth, P. Tempst, A. Winoto, L. Fors, L. E. Hood, and H. N. Antoniades. 1984. Detection of c-sis transcripts and synthesis of PDGF-like proteins by human osteosarcoma cells. Science (Wash. DC). 226:972-974.

38. Nistér, M., C.-H. Heldin, Å. Wasteson, and B. Westermark. 1982. A platelet-derived growth factor analog produced by a human clonal glioma cell line. Ann. NY Acad. Sci. 397:25-33.

39. Barret, T. B., C. M. Gajdusek, S. M. Schwartz, J. K. McDougall, and E. P. Benditt. 1984. Expression of the sis gene by endothelial cells in culture and in vivo. Proc. Natl. Acad. Sci. USA. 81:6772-6774.

40. Shimokado, K., E. W. Raines, D. K. Madtes, T. B. Barrett, E. P. Benditt, and R. Ross. 1985. A significant part of macrophagederived growth factor consists of at least two forms of PDGF. Cell. 43: 277-286.

41. Leibovich, S. J., and R. Ross. 1976. A macrophage-dependent factor that stimulates the proliferation of fibroblasts in vitro. Am. J. Pathol. 84:501-514.

42. Wewers, M. D., S. I. Rennard, A. J. Hance, P. B. Bitterman, and R. G. Crystal. 1984. Normal human alveolar macrophages obtained by bronchoalveolar lavage have a limited capacity to release interleukin 1 . J. Clin. Invest. 74:2208-2218.

43. Rennard, S. I., G. W. Hunninghake, P. B. Bitterman, and R. G. Crystal. 1981. Production of fibronectin by the human alveolar macrophage: mechanism for the recruitment of fibroblasts to sites of tissue injury in interstitial lung diseases. Proc. Natl. Acad. Sci. USA. 78:71477151. 